\title{
Accounting Learning Management on Curriculum 2013 Based on Lesson Study at Vocational School Surakarta
}

\author{
Suyatmini $^{1,{ }^{*}}$, Yetty Sarjono ${ }^{1}$, Titik Asmawati ${ }^{1} \&$ Wafrotur Rohmah ${ }^{1}$ \\ ${ }^{1}$ Accounting Education, University of Muhammadiyah Surakarta, Indonesia \\ *Correspondence: Accounting Education, University of Muhammadiyah Surakarta, Indonesia. \\ E-mail: Suyatmini@ums.ac.id
}

Received: August 24, 2015 Accepted: October 28, 2015 Published: December 20, 2015

doi:10.5296/ije.v7i4.8763 URL: http://dx.doi.org/10.5296/ije.v7i4.8763

\begin{abstract}
The research aim is to describe management learning accounting on curriculum 2013 that is conducted by Vocational School teachers at Surakarta. Data gathering methods used are; interview, observation, and documentation. Data analysis technique used is interactive analysis that is involved data gathering, reduction, display, and verification. The research result showed that not all of accounting teachers at Vocational School Surakarta in arranging planning of learning conducting, learning conducting and accounting learning evaluation to implement curriculum 2013. Vocational School curriculum at Surakarta still using two curriculums, those are; Education set level curriculum and curriculum 2013. It still can be found that there are some problems on accounting Vocational School teachers at Surakarta in related with curriculum 2013 involving the difficulty in arranging the learning set of curriculum 2013, the problems on accounting learning process used scientific approach, or difficulty in authentic evaluation.
\end{abstract}

Keywords: Curriculum management; conducting; evaluation; planning 


\section{Introduction}

In order to increase the education quality one of the best ways that is conducted by doing education system innovation. According to Nurhadi (2001:1) there are three components that need to throw light on education innovation, those are; curriculum innovation, learning quality increasing, and learning method effectivity. Although, curriculum that is used in Indonesia keep doing improvement for making reality of the best education, one of the problems that is faced by education world nowadays is the weakness of learning process. The existing learning process up to now only tends to make students got very heavy loaded with material and duties that is given by the teachers. By material and duties that is given by teachers, so that students felt bored in the classroom. Accounting lesson tends regarded as "unlike lesson" or "if it can be avoided" by part of students and lack of patience that the exist accunts in accounting lesson to teach students for thinking rational, accurate, efficient and effective. Because of that, teacher' creativity in accounting teaching to be one of important factors in order that accounting to be interesting lesson and lovely in the classroom, for investement, giving credit and the other decision. In the reality most of teachers have not understood the content standard, lack of ability in developing syllabus and important material; also teachers have difficulty in formulating indicator. Teachers in teaching were still oriented to the books, abstract, and only a few teachers who relate the learning material with the students' life. Therefore, teachers did not know the students' beginning condition so that they could not motivate students to study seriously (Sutama, 2011: 28-32). It should be in learning process teachers can use environment as learning basis, because can help teachers and students in reaching up the learning goal. (Sarjono dan Suyatmini, 2014: 12). The similar thing is also done by (Non Government Organization) NGO Sari in doing learning process (Sarjono and Suyatmini: 2013: 102). In learning process that is based on enevironment also be able to stimulate students for independence/standing alone. It is also in problem based learning, the research result showed that classroom situation to be more active and creative to increase students independence attitude (Wafroturrohmah and Suyatmini, 2008: 162).

Based on thinking above and in stressing condition " to apply curriculum 2013 soon", it is better for teachers to focus on learning management by doing accurate strategy that is suitable with the need of students, mainly; by developing accounting learning on curriculum 2013 that is based on lesson study. Accounting learning on curriculum 2013 with scientific approach, (Depdikbud, 2014:69) so that be able to stimulate students' view in order to response environment. Lesson study as model of educator profession guiding through learning study colaboratively and continually based on colegiality principals "mutual learning" for study community building (Susilo, dkk., 2009: vi). This is suitable with conducting principal on curriculum 2013, mainly students should get excellent education service, also to get oppurtunity for expressing themselves freely, dynamically, and lovely.

At the field condition showed that there is general impression, accounting teachers' ability in apllying curriculum 2013 have not suitable with thye hope. Most of them, still get predicate as curriculum executor and even the activities that are conducted by them just as the rutinity. Teachers have not ready to face many changing, access for sophisticated material is limited, view and learning skills is also limited. Learning that they are conducted is dried and useless 
Accounting that is presented for students just only the boring numbers collection. Students did not know what for they study accounting. Text books or learning material that is used teachers absolutely go away from accounting learning goal. The books that are fulfilled by principals and item tests collection that the truth is determined by teachers authority. It is more sadness, those books were used by teachers as the main source for assessment of study result. Cockroft (1982) stated that students need study accounting with reason that accounting as very strong, accurate, and not confusing equipment communication. But, accounting learning approach at Vocational School Surakarta showed that most of them still centered at teachers. It is called as teaching activity, not learning activity. Teachers' domination in teaching can cause accounting learning communication not effective. Therefore, teachers' creativity in accounting teaching to be one of important factors in order accounting to be interesting and lovely lesson. Hamalik (2008: 11) stated that good teachers not only mastering their specialize science, but also should familiar with human being study process, the way to teach, the usage of equipment display, assessment technique.

The problem that need to be overcome soon, mainly; accounting teachers ability at Vocational School Surakarta in developing learning management on curriculum 2013. Suitable Learning strategy with accounting material teaching on curriculum 2013. The development of accounting learning management on curriculum 2013.

Generally this research is directed for describing accounting learning management on curriculum 2013 that is conducted by Vocational School teachers at Surakarta which involved: (a) describing the planning of accounting learning management on curriculum 2013 that is arranged Vocational School teachers at Surakarta ; (b) describing the conducting of accounting learning management on curriculum 2013 that is conducted by Vocational School teachers at Surakarta; and (c) describing accounting learning evaluation on curriculum 2013 that is conducted by Vocational School teachers at Surakarta.

\section{Research Method}

The research kind is qualitative, according to Sutama (2012:61-62) qualitative research gives stressing on understanding and meaning, linked tightly with the certain value, more stressing on process than measurement, describing, interpreting, and giving meaning, and not enough with explanation only, and to use multi methods in research. Qualitative research tends to analyse data that they got with inductively. Vocational School Teachers research subject, at Surakarta, research data gathering method used are, interview, observation, and documentation. Data analysis technique used is interactive analysis that is involved data gathering, reduction, display, and verification. (Miles and Huberman, 2007: 20).

\section{The Research Result and Discussion}

Accounting learning management on curriculum 2013 that is conducted by Vocational School teachers at Surakarta involved: 
3.1 The planning of accounting learning conducting on curriculum 2013 that is done by vocational school teachers at Surakarta

From the interview result with Vocational School accounting teachers at Surakarta showed that Learning Conducting Planning arrangement should be suitable with syllabus and curriculum that has established. Teachers' activity in arranging learning material refers to basic and standard competence that wrote down on syllabus. Syllabus development in the form of planning of accounting learning conducting that will be tought by teachers in the classroom, because a teacher should has planning in conducting teaching learning process, if teacher did not arrange Learning Conducting Planning so teaching learning activity in the classroom will not run well and successful and will create clear cut in the class.

Based on interview and observation result from researcher were showed that not all of accounting teachers at Vocational School Surakarta in arranging planning of learning conducting have applied curriculum 2013. Vocational School curriculum at Surakarta still using two curriculums, those are; Education Set Level Curriculum and curriculum 2013, Researcher observation on students class XI and XII still using Education Set Level Curriculum combined with curriculum 2013. While curriculum 2013 is begun on students class X and etc. It is relevance with Kirkham' research (2013:77) stated that curriculum approach can increase effective learning and good experiences for understanding accounting that is in line with curriculum and as a good approach for students in learning accounting. Research can be meant, that curriculum approach for increasing study experience in accounting, and for increasing students study achievement.

The preparation of Vocational School accounting teachers at Surakarta in understanding accounting syllabus curriculum 2013 still finding difficulty in understanding the concept of Core Competence and Basic Competence curriculum 2013. Vocational School accounting teachers at Surakarta were finding difficulty in analyzing the suitability between Core Competence and Basic Competence in curriculum 2013. In understanding syllabus curriculum 2013 , indicator that is used involving accounting teachers understanding towards the picture of core and basic competence, and the suitability of Core Competence and Basic Competence on curriculum 2013. The lack of understanding that is showed by Vocational School accounting teachers at Surakarta in this research result showed that the new accounting teachers understood the concept of Core Competence and Basic Competence curriculum 2013 only in the great line. This lack of understanding can't separated from the problem that not all of Vocational School accounting teachers at Surakarta for getting socialization and training for implementing curriculum 2013 from Surakarta city government.

Vocational School accounting teachers at Surakarta in arranging Learning Conducting Planning that is suitable with curriculum 2013 have difficulty in formulating indicator competence achievement by using the right operational verb and problem in formulating students' learning goal. Accounting teachers did not pay attention "condition aspect and degree in formulating learning goal, so that students' competence achievement can't measure objectively. Accounting teachers also did not write down instrument and rubric assessment on students' attitude that is arranged in Learning Conducting Planning Accounting curriculum 
2013. In this research which to be research indicator is accounting learning management curriculum 2013 linked with the planning of accounting learning management/accounting teachers in arranging Learning Conducting Planning Accounting curriculum 2013 involving accounting teachers' ability in formulating indicator students' competence achievement, learning goal, main material, certain time allocation, learning aim that is formulated based on Basic Competence, learning method, media, equipment, and learning sources, learning activities stages/steps, and determining the kinds of authentic assessment.

\subsection{Accounting learning conducting on curriculum 2013 that is done by vocational school teachers at Surakarta}

From the interview result with Vocational School accounting teachers at Surakarta showed that accounting learning conducting by using scientific approach have been implemented. But not all of scientific activity has done. Observing activities is done by students through reading accounting theory from accounting Students Work Sheet, but the rest of that is listening teachers' explanation on white board as long as accounting theory giving. Thinking activity has not implemented because students seem passive and still have difficulty to solve the item test where the answer is not written down on accounting Students Work Sheet, information gathering activity that is done by active students, while the other students felt uninteresting in following group job for collecting accounting information together.

From the observation and interview result researcher found that student individual attitude more dominant compared with student attitude for working together in group. Students feel more satisfied with study result that they got individually and for themselves compared with study result that they got from group and for the group importance. It is showed that students have not recognized that the group succeed depended on the individual succeed. They have not recognized that the disability one of the group members can decrease the group succeed. The students were rarely in questioning showed that students were not active in teaching learning process. Some students were often asking about material that is thought in learning, but the rest of students did not ask about material that is learned while the learning process was going on.

Therefore, asking activity and question also to communicate exactly was taken over by Vocational School accounting teachers, it is in line with curriculum 2013, and students should be done asking and communicating activity. It showed that most of accounting teachers have no understood application concept about scientific approach in accounting learning management on curriculum 2013.

\subsection{Accounting learning evaluation on curriculum 2013 that is conducted by vocational school accounting teachers at Surakarta}

Evaluation in accounting learning of Vocational School at Surakarta involving; affective, psychomotoric and cognitive evaluation which the three all as continually among attitude, skill, and academic that should be owned by students. Aspect that should be valued in evaluation, such as; spiritual their belief to Allah SWT/ God, The Almighty, will be valued in together praying/sholat which is done when they will go home, so that teachers can observe students attitude towards their belief to Allah SWT. For psychomotoric evaluation or skill, 
teachers can observe and give task/duty that make their thinking to be faster in completing their task/duty giving by teachers, the assessment process can be formed as portfolio task and conducted when accounting learning material is going on in the classroom. While in cognitive assessment such as; written and oral test or doing task/duty that are conducted in daily test, mid semester test, and final test. Evaluation result can be formed as the last result of final test, report, and students can know that accounting score and teachers understand about the students' ability.

Before teachers doing evaluation of study result, so they should learning carefully about curriculum. This learning curriculum is meant to observe study result types that mentioned in formulating of basic competence and indicator. By understanding that study result types, teachers will choose and determine evaluation instrument and technique accurately. For example; the formulating of competence and its indicator contain of study result type is cognitive study result the leveling of understanding, so the evaluation technique that can be used is objective test, such as; multiple choice or essay. If the study results types is psychomotoric, so the suitable evaluation technique is by using perform test and the instrument in the form of Sukiman assessment scale (2012: 40).

The appropriate assessment for education will give result that is in line with the hope, because education assessment is collecting process and information cultivation for determining students study result achievement Hamdani (2011: 301). The education assessment is very important, because to know students' ability in accounting learning. Besides assessment affectively, psychomotoric, and cognitive, the assessment that is conducted by teachers on students in the form of formative test that is directed to improve teaching learning process, that is done in the end of main topic discussion, while summative test is directed to create progressing numbers/scoring students study result. Evaluation basically is to know the last result in active learning that involved science, skill, attitude, and values that is formed in thinking habitual and action. It will make students enthusiastic in accounting learning for reaching up the best result for understanding accounting. Evaluation in accounting learning is variant so that not boring, similar with evaluation in the task/duty and group form, it will make students more creative and active in understanding accounting.

Integrated learning evaluation, as students' basic competence achievement assessment is conducted based on indicator. The assessment is used Penilaian digunakan menggunakan using test or non test in written or oral form, job observation, attitude measurement, the assessment of practicing result, such as; task/duty, project, and or product, portfolio usage, and self assessment, Trianto (2010: 123). From the stages aspect, evaluation both it is done on planning stage or on conducting. While from target aspect, evaluation focus on process or learning product.

Evaluation aim is to know students' absorbing in accounting learning towards material giving by teachers in the form item test to know students' ability. The assessment by giving appropriate item test will produce effective and efficient barometer that is able to give the best result that is hoped in line with Minimum Completing Creteria and increase the quality of accounting learning. Evaluation of accounting learning is also variant; it is done both 
grouply and individually, grouply evaluation is based on that group. While individual evaluation is based on the result of individually both on oral or written or through duty/task giving.

Curriculum has grown up as important factor in preparing accounting students for better job in the future. In conceptual framework has proved for offering many potential useful for curriculum design evaluation and future research can give tighter examination from framework on variant development stages. It can be seen from quality also has shown potential that is used to determine curriculum relevance on topic level every week and maybe as the approachment that is researcher done also found several assessment criteria that is useful for students, such as; assessment criteria in accounting according to Laing (2012:1).Interaction from computer application can develop students evaluation about their attitude assessment of accounting, assessment by using computer is also very effective that has apllied on curriculum level. It can be meant that assessment from Laing to show up on curriculum level on students' attitude evaluation, similar with Vocational School at Surakarta that is based on the existence of Education Set Level Curriculum or curriculum 2013. Although most of Vocational School accounting teachers at Surakarta still have difficulty in making authentic assessment on curriculum 2013.

\section{Conclusion}

Based on the research result, so it can be concluded that accounting learning management on Curriculum 2013 that is involving the planning of accounting learning conducting on curriculum 2013, accounting learning evaluation and conducting learning have not done by most of Vocational School accounting teachers at Surakarta. Vocational School curriculum at Surakarta still using two curriculums, those are; Education Set Level Curriculum and curriculum 2013. It still can be found some problems on accounting Vocational School teachers at Surakarta in related with curriculum 2013, involving the difficulty in arranging the learning set of curriculum 2013, the problem on accounting learning process used scientific approach, or difficulty in authentic evaluation.

\section{References}

Alleyne, Philmore \& Diana Weekes-Marshall. (2011). An Exsploratory Studyof Management Accounting Practices In manufacturing Companies in Barbado. of Business International Journal and Social Science, 2(9) (Special Issue-May 2011), 49-58

Anwar. (2006). Penggunaan Peta Konsep Melalui Model Pembelajaran Kooperatif Tipe STAD untuk meningkatkan Proses, Hasil Belajar, dan Respons pada Konsep Ekosistem. Dalam Jurnal Penelitian Kependidikan, 16(1), 217-244.

Dallimore, Elice. J., Hertenstein Julie H., \& dan Platt Majorie B. (2010). Class Participation in Accounting Courses: Factors That Affect Student Comfort and Learning American Accounting Association. Issues In Accounting Education, 25(4), 613-629. 
http://dx.doi.org/10.2308/iace.2010.25.4.613

Depdikbud. (2014). Materi Pelatihan Guru Implementasi Kurikulum 2013 Tahun Ajaran 2014/2015. Jakarta: Penerbit BPSDMPK dan PMP.

Djamarah, Syaiful Bahri dan Aswan Zain. (2010). Strategi Belajar Mengajar. Jakarta: Rineka Cipta.

Eck, Richard Van \& Jack Dempsey. (2002). The effect of Competition and Contextualitied Advisement on the Transfer of Mathematics Skill in a Computer-Based Instruksionaly Simulation Game. Journal from Academy International of Journal http://proquest.umi.com/pqdweb?id=690191641\&sid $=4 \& f m t=4 \&$ clientid $=80413 \& R Q T$ $=309 \&$ Vname $=P Q D$. Diakses pada Sabtu24 Oktober 2009

Gregory Kenneth, Laing. (2012). Higgher Education Studies Published by Canadian Center of Science and Education I integration of acomputer Application in a first Year Accounting Curriculum: An Evaluation of Student Attitudes, School of Accounting \& Finance, Faculty of Commerce University of Wollongong, Australia, 2(2), June 2012.

Hamalik, Oemar. (2007). Manajemen Pengembangan Kurikulum. Bandung: PT. Remaja Rosda Karya..

Hamdani. (2011). Strategi Belajar Mengajar. Bandung: Pustaka Setia.

Iskandar, Srini M. (2006). Peningkatan Kualitas Pembelajaran Dasar-Dasar Sains dengan Mengggunakan Pembelajaran Berkelompok (Learning Together) dan Pembelajaran Timbal Balik (Reciprokal Teaching)”. Dalam Jurnal Penelitian Kependidikan. Tahun 16 Nomor 1 Juni.

Kirkham, Ross. (2013). An Approach to Improving the Learning Experience for First Year Accounting Currriculum University of the Sunshine Coast, Australia. E-Journal of Business Education \& Scholarship of Teaching, 7(1), 74-81.

Lestianto. (2011). Implementasi Model Pembelajaran Kooperatif CIRC berbasis lesson Study untuk meningkatkan asil belajar siswa untuk mata kuliah kewirausahaan.Malang: FE, UM.

Martini, dkk. (2006). Meningkatkan Kemampuan Aspek Psikomotr Melalui Pembelajaran Berbasis Laboratorium pada siswa Kelas XI IPA I SMA Negeri I Jombang. Dalam Jurnal Penelitian Kependidikan, 16(2), 245-255.

Miles, Matthew B. dan A. Michael Huberman. (2007). Analisis Data Kualitatif. Terjemahan Tjetjep Rohendi. Jakarta: Penerbit Universitas Indonesia.

Ninih Rochanah dkk. (2012). Pengembangan Model pembelajaran Berorientasi Konstruktivistik Untuk Meningkatkan Kualitas Pembelajaran Akuntansi di SMA. Jurnal Pendidikan

O'Leary, Conor dan Stewart Jenny. (2012). J Bus Ethics Accounting and Law Discipline, Griffith Business School. The Interaction of Learning Styles and teaching 
Methodologiesin Accounting Ethical Introction, Nathan Campus, Griffith University, 170 Kessels Road, Nathan, dan Griffith University, Logan Campus, Logan Australia 113: 225-241

Puput. (2013). Pengembangan bahan ajar akuntansi Berbasis Kolaborative Learning, pou-pout.blogspot.com/2013/08 pengembangan bahan -ajarakuntansi, html, diakses 15 oktober 2013.

Riccio, Edson. I. dan Sakata, Marici, C.G. (2005). Teaching Learning Method In Accounting Education-an Empirical Research In the Brazilian Scenario Brazil: University of sao Paulo. P.1-14

Sarjono, Yetty dan Suyatmini. (2011). Model penataan Pedagang Kaki Lima di Surakarta Sebagai Solusi Konstruktif Untuk Pemberdayaan Tingkat Pendidikan Anak-anak PKL. EDUKASI, Jurnal Ilmu pendidikan, 10(2), 1-8

Sarjono, Yetty dan Suyatmini. (2013). Model Pendidikan Anak-Anak Miskin di Kota Surakarta. Jurnal Manajemen Pendidikan, 8(2), 98-111.

Sarjono, Yetty. dan Suyatmini. (2013). Pengembangan Model Pembelajaran Ekonomi Berbasis Lingkungan Dengan pendekatan pembelajaran Inovatif di SMA Muhammadiyah di Surakarta, Laporan penelitian Pentaspena, Juni 2013.

Sugiyono. (2006). Metode Penelitian Kuantitatif, Kualitatif dan R\&D. Bandung: Alfabeda.

Sukiman. (2012). Pengembangan Sistem Evaluasi. Yogyakarta: Insan Madani

Susilo, Herawati, Husnul Chotimah, Ridwan Joharmawan, Jumiati, Yuyun Dwita Sari, dan Sunarjo. (2009). Lesson Study Berbasis Sekolah. Malang: Bayumedia Publishing.

Sutama. (2012). Metode Penelitian pendidikan (Kuantitatif, Kualitatif, $P T K, \quad R \&$ D). Gumpang -Kartasura: Fairus Media.

Suwarni, Endah, Retno Widiastuti, dan Anna Isrowiyah. (2007). “'Accelereted Learning' sebagai Dasar untuk Meningkatkan Efektivitas dan Efisiensi Proses Balajar Mengajar Akuntasi Pangantar". Makalah Simposium Nasional 2007. Jakarta 26-27 Juli 2007. Pusat Penelitian Kebijakan dan Inovasi Pendidikan, Badan Penelitian dan Pengembangan, Departemen Pendidikan Nasional Republik Indonesia.

Suyatmini. (2012). Analisis Dampak Struktur Kepemilikan Terhadap Kebijakan Finansial Dalam Perspektif Teori Keagenan. Jurnal pendidikan Ilmu Sosial, 22(1), 72-80.

Trianto. (2010). Model Pembelajaran Terpadu Konsep Strategi, dan Implementasinya da/am Kuriku/um Tingkat Satuan Pendididkan (KTSP). Jakarta: Bumi Aksara.

Undang- Undang No.20 tahun. (2003). Tentang Sistem pendidikan Nasional. Bandung: Cipta Umbara.

Wafroturrohmah dan Suyatmini. (2008). Penggunaan Metode Problem Based Learning Untuk meningkatkan Kemampuan Belajar Mandiri Mahasiswa Jurusan Pendidikan Akuntansi 
Pada Mata Kuliah akuntansi Perpajakan. Jurnal Varia Pendidikan, 20(2), 154-163.

Vincent. (2012). Using Learning Study To Improve The Teaching And Learning of Accounting in a School In Brunei Darusalam. International Journal For Lesson And Learning Studies, 1(1), 23-40.

\section{Copyright Disclaimer}

Copyright for this article is retained by the author(s), with first publication rights granted to the journal.

This is an open-access article distributed under the terms and conditions of the Creative Commons Attribution license (http://creativecommons.org/licenses/by/3.0/). 